\title{
A Response to the Views of Medical Students Towards Learning Communication Skills from Chitwan Medical College [Letter]
}

This article was published in the following Dove Press journal: Advances in Medical Education and Practice

\section{Ishwar Singh Malhi \\ Mohammed Bilal Khan}

Manchester Medical School, Faculty of Biology, Medicine and Health University of Manchester, Manchester, UK
Correspondence: Ishwar Singh Malhi; Mohammed Bilal Khan

Manchester Medical School, Faculty of Biology, Medicine and Health University of Manchester, Manchester, UK Email ishwar.malhi@student. manchester.ac.uk; mohammed.khan-19@student. manchester.ac.uk

\section{Dear editor}

We would like to extend our gratitude to the contributing writers of this article in providing an insight into the attitudes of recently admitted undergraduate medical students on learning communications skills from Chitwan Medical College, Bharatpur, and would like to present some of our comments on the study. ${ }^{1}$

The article demonstrates that there is a need to integrate communication skills into the current college curriculum, finding that a large proportion of students were not aware of the importance of communication skills for a physician $(n=24)$, with almost half unsure about the ability to learn the skill itself $(n=40) .{ }^{1}$ Nevertheless, as highlighted in the paper, the small sample size based on a single university's applicants ( $\mathrm{n}=99)$ impedes the ability to compare and contrast the study, in turn limiting its generalizability. Moreover, the characteristics of participants within the questionnaire included their prior educational institutions, yet the relevance of this has not been identified. Further investigations into whether there is a connection to the aforementioned would highlight any significance.

The authors found that cultural differences within Nepal may have resulted in disparity in the learning of communication skills between genders. ${ }^{1}$ Additional research should be undertaken to look specifically at the foundation of communication skills and whether students find them relevant to the medical profession, observing these changes between male and female students. Graf et $\mathrm{al}^{2}$ identified contrasting differences in the dimensions of these abilities (empathy, structure of communication, verbal and non-verbal expression) between genders, so adding questions applicable to these within an alternative questionnaire may reveal greater variation.

Correspondingly, the writers have not suggested a practical method to incorporate communication skills into the college syllabus, given the conclusions of the study. In comparison, in the UK, there is an extreme emphasis on the necessity of these skills for any prospective student prior to their medical school application. ${ }^{3}$ Through a vigorous selection process, pupils should illustrate the use of various extracurricular activities, shadowing in healthcare environments, and other relevant experiences within their personal statement and following interview; in turn, identifying the acquired skills from each activity and demonstrating how they are applicable to the medical profession (team work, empathy, leadership and decision making are all further examples of these). ${ }^{3}$ 
Furthermore, communications skills training (CST) has become compulsory for all UK medical schools, incorporating the use of simulated patients, group discussion and video feedback within allocated sessions throughout the academic timetable. ${ }^{4}$ The majority of schools provide this teaching within years 1 and 2, forming a solid pre-clinical foundation before entering clinical years. One example includes integrating the Calgary Cambridge Model, a systematic approach to patient consultations used for a patient-centered approach. ${ }^{5}$ Further steps must be taken by the medical college to exemplify the importance of these skills.

Overall, we found that this article encapsulated an informative yet comprehensive look into the views of recently admitted medical students on communication skills. Further research into different factors impacting the views of students in comparison to medical schools in developed countries could provide stronger supporting evidence.

\section{Disclosure}

The authors report no conflicts of interest in this communication.

\section{References}

1. Timilsina A, Karki S, Singh J. Attitudes of recently admitted undergraduate medical students towards learning communication-skills: a cross-sectional study from Chitwan Medical College. Adv Med Educ Prac. 2019;10:963-969. doi:10.2147/amep.s229951

2. Graf J, Smolka R, Simoes E, et al. Communication skills of medical students during the OSCE: gender-specific differences in a longitudinal trend study. BMC Med Educ. 2017;17(1). doi:10.1186/s12909-017-0913-4

3. Kreier C, Axelson R. A perspective on medical school admission research and practice over the last 25 years. Teach Learn Med. 2013;25(sup1):S50-S56. doi:10.1080/10401334.2013.842910

4. Hargie O, Boohan M, McCoy M, Murphy P. Current trends in communication skills training in UK schools of medicine. Med Teach. 2010;32(5):385-391. doi:10.3109/01421590903394603

5. Main C, Ruchbinder R, Porcheret M, Foster N. Addressing patient beliefs and expectations in the consultation. Best Pract Res Clin Gastroenterol. 2010;24(2):219-225. doi:10.1016/j.berh.2009.12.013

Dove Medical Press encourages responsible, free and frank academic debate. The content of the Advances in Medical Education and Practice 'letters to the editor' section does not necessarily represent the views of Dove Medical Press, its officers, agents, employees, related entities or the Advances in Medical Education and Practice editors. While all reasonable steps have been taken to confirm the content of each letter, Dove Medical Press accepts no liability in respect of the content of any letter, nor is it responsible for the content and accuracy of any letter to the editor.

\section{Publish your work in this journal}

Advances in Medical Education and Practice is an international, peerreviewed, open access journal that aims to present and publish research on Medical Education covering medical, dental, nursing and allied health care professional education. The journal covers undergraduate education, postgraduate training and continuing medical education including emerging trends and innovative models linking education, research, and health care services. The manuscript management system is completely online and includes a very quick and fair peer-review system. Visit http://www.dovepress.com/testimonials.php to read real quotes from published authors. 